\title{
The glorious fossil record
}

The fossil record may not be complete for all groups at all times and in all places. But, argues Dr Paul Pearson, when we have reason to believe that it is, the dates that can be assigned to fossils are invaluable for unravelling the paths of evolution.

\section{PAUL PEARSON}

In The Origin of Species, Charles Darwin lamented that the imperfection of the fossil record detracts from the glory of geology. Fossilization is such a rare and capricious event, our collections are so poor, and sedimentary formations are so full of gaps, that Darwin could not point to a single example where fossils in successive geological strata showed evolution from one species to another.

Unknown to Darwin, uninterrupted sedimentation does occur in the open ocean, especially on aseismic ridges and plateaux. These areas experience a continuous rain of particles to the sea bed, and are among the most geologically quiescent places on Earth. A steady build-up of sediment is the result.

Now, after thirty years of systematic ocean drilling, many of these sites can be studied. Piston coring generally allows hundreds of meters of sediment to be fully recovered, spanning millions of years of deposition. Where gaps occur, they can easily be identified.

\section{A continuous sediment}

A good example of this is ODP Site 926 on the Ceara Rise, western equatorial Atlantic. As far as we can tell from biostratigraphy, this site has been sedimenting continuously for about 60 million years ${ }^{1}$. Regular and gradual changes in the Earth's orbit affect the chemical composition of sediments which allows us to prove that there are no significant gaps whatsoever in the record for the last 14 million years ${ }^{2}$. The activity of burrowing animals is the main factor that limits our temporal resolution, but the effect is generally negligible over evolutionary time-scales.

Sites like this are well appreciated by paleoceanographers. Many detailed chronologies of chemical and environmental change in the oceans have been reconstructed from them. Biologists, on the other hand, seem curiously reluctant to "unlearn" the difficult lesson of the supposedly incomplete fossil record.

\section{Tracing evolution}

The sediments in question are composed mainly of the shells of microscopic plankton such as foraminifera, radiolaria, diatoms and coccolithophorids. Large numbers of individuals can easily be extracted. Their evolution can be followed through geological time, simply by comparing one closely spaced sample with the next. This reveals morphologically isolated and continuous lineages which it is reasonable to infer represent lines of genetic descent $\frac{3-6}{}$. These lineages sometimes split from one another $\frac{7-8}{}$, and often evolve gradually over vast periods of time, or become extinct.

Recent DNA sequencing on modern planktonic microorganisms allows us to put such data into context. Although there is some debate about possible "cryptic species" in the modern plankton?, the genetic and fossil data are in broad agreement $\frac{10-11}{}$. This is encouraging for everyone involved.

Does the fossil record provide a true and accurate record of first and last 
occurrences of species? Emphatically, the answer is yes! Microfossils are used routinely for biostratigraphic correlation by thousands of specialists the world over. This would not be possible unless the sediment record was good and reliable. We now know (within fairly precise limits) when hundreds of species of mineralizing plankton arose and became extinct, through a history that spans over a hundred million years.

\section{Stratigraphy's place}

The key question of this debate is when and how stratigraphic information should be brought into play when reconstructing phylogenies. The answer to most micropalaeontologists is clear. Stratigraphy is paramount. Many possible hypotheses of ancestry can be immediately rejected on this evidence alone. We generally determine phylogeny by finding specimens of the actual forms that link species together $\frac{12-13}{}$.

The standard approach to phylogenetic analysis used by the rest of the community is cladistics. It is also a useful tool ${ }^{14}$. However, it has some drawbacks in micropalaeontology. In essence, cladograms rely on tabulating the distribution of 'characters' in a set of taxa. That information is used to infer the most likely branching pattern that could have produced the species in question. There is usually no reference to either the relative stratigraphical position of species, or evidence such as whether or not two forms are part of a single evolving lineage. Consequently, cladograms omit data that are central to our approach (sometimes called 'stratophenetics' 15 ).

We know from our well-sampled fossil record that there have been many episodes of evolutionary convergence. Also, our fossils tend to be somewhat 'character poor'. This means that in many cases, distantly related species have evolved similar shapes and features at different times. Making cladograms would be no help in these instances, but stratigraphy often is.

Another problem is that cladograms necessarily portray all taxa as sisters, even if we believe from stratigraphy that some were ancestral to others. All things being equal, at least half of all species in the past must have been ancestral to at least one other species. Consequently, cladistic analyses of extinct groups of organisms (clades) tend to greatly overestimate the extent of branching. If we want to study rates of evolution using fossils, this can be seriously misleading.

\section{All data have their worth}

My plea is for pluralism in phylogenetics. For too long, cladists have defined themselves by contrasting their approach with 'traditional' taxonomists of previous generations. The textbook catechism has been that old fashioned stratigraphical studies are necessarily subjective or even unscientific, and cladograms offer the only objective method of getting at the truth. In general the practice of 'ancestor hunting' is denigrated.

However, we should acknowledge that any given evolutionary transition was an actual historical sequence of organisms. It is not necessarily futile to search for vestiges of them, taking particular care to sample sediments of the right age and environment. For some fossil groups this may well be the optimal approach. For most groups, a combination of cladistic and stratigraphical evidence will yield maximum information.

Unfortunately, I see no easy way of incorporating stratigraphic information within a character matrix, and thereby including it in a cladogram based on 'total evidence'. In my view, the best approach to phylogenetics will involve considering the various types of data (comparative morphology, genetics and stratigraphy) separately. These will have to be weighed against each other by a well informed specialist.

Paul N. Pearson

Department of Earth Sciences, University of Bristol, Bristol,United Kingdom 


\section{References}

1. Shipboard Scientific Party. Site 926. Proceedings of the Ocean Drilling Program, Initial Reports 154, 153-232 (1995).

2. Shackleton, N.J. \& Crowhurst, S. Sediment fluxes based on an orbitally tuned time scale 5 Ma to $14 \mathrm{Ma}$, Site 926. Proceedings of the Ocean Drilling Program, Scientific Results, 154, 69-82 (1997).

3. Kellogg, D.E. Phenology of morphometric change in radiolarian lineages from deep sea cores: implications for microevolution. Paleobiology 9, 335-363 (1983).

4. Malmgren, B.A. \& Berggren, W.A.. Evolutionary change in some late Neogene planktonic foraminifera lineages and their relationships to paleoceanographic change. Paleoceanography 2, 445-456 (1987).

5. Wei, K-Y. Allometric heterochrony in the Pliocene - Pleistocene planktic foraminiferal clade Globoconella. Paleobiology 14, 345-363 (1994).

6. Hodell, D.A. \& Vayavananda, A. Early middle Miocene paleoceanography of the western equatorial Pacific (DSDP Site 289) and the evolution of Globorotalia (Fohsella). Marine Micropaleontology, 31, 279-310 (1993).

7. Sorhannus, U., Fenster, E.J., Burckle, L.H. \& Hoffimann, A. Cladogenetic and anagenetic changes in the morphology of Rhizosolenia praeburgonii Mukhina. Historical Biology 1, 185-205 (1988).

8. Lazarus, H., Hilbrecht, H., Spencer-Cervato, C. \& Thierstein, H. Sympatric speciation and phyletic change in Globorotalia truncatulinoides. Paleobiology 21, 975-978 (1995).

9. Huber, B.T., Bijma, J. \& Darling, K. Cryptic speciation in the living planktonic foraminifer Globigerinella siphonifera (d'Orbigny). Paleobiology 23, 33-62 (1997).

10. Darling, K.F., Wade, C.M., Kroon, D. \& Leigh Brown, A.J. Planktonic foraminiferal molecular evolution and their polyphyletic origins from benthic taxa. Marine Micropaleontology 30, 251-266 (1997).

11. De Vargas, C., Zaninetti, I., Hilbrecht, H. \& Pawlowski, J. Phylogeny and rates of molecular evolution of planktonic foraminifera SSU rDNA sequences compared to the fossil record. J. Molec. Evol. 45, 285-294 (1997).

12. Fordham, B.G. Miocene- Pleistocene planktic foraminifers from DSDP Sites 208 and 77, and phylogeny and classification of Cenozoic species. Evolutionary Monographs 6, 1-200 (1986).

13. Pearson, P. N. A lineage phylogeny for the Paleogene planktonic foraminifera. Micropaleontology 39, 193-232 (1993).

14. Berggren, W.A. \& Norris, R.D. Biostratigraphy, phylogeny and systematics of Paleocene trochospiral planktic foraminifera. Micropaleontology 43 (Suppl. 1), 1-116 (1997).

15. Gingerich, P.D. Stratophenetics. in Paleobiology: a synthesis (Briggs, D.E.G. \& Crowther, P.R. eds) 437-442 (Blackwell Scientific, Oxford, 1990). 